\title{
【特 集：エコデザイン】
}

\section{日産自動車におけるリサイクル設計の取り組み}

東 畑透*

【要 旨】自動車のリサイクル率は現状においても80\%を超え，工業製品の中では高いリサイクル率 を実現しているが，新しいリサイクル法により 2015 年に $95 \%$ 以上という高いリサイクル率を実現する 必要がある。

リサイクル率を向上するために，新車開発段階での $3 \mathrm{R}$ （Reduce, Reuse, Recycle）を考虑した軽 量化やリユース・リサイクルしやすい設計への取り組みと廃車処理段階での処理・再利用技術の開発を 実施している。

本報告では，自動車リサイクルの現状と日産自動車のリサイクル設計の取り組みについて，および， 今後求められる自動車リサイクルの技術, 課題を紹介する。

キーワード：自動車, リサイクル

1.はじめに

日本では年間約 500 万台発生する使用済自動車は, 有 用な金属・部品を含み，資源として価值が高いものであ るため, 従来から解体事業者やシュレッダー事業者にお いて, 売買を通じて流通し, リサイクル・処理が行われ てきた。

一方, 産業廃率物最終処分場の逼迫により使用済自動 車から発生するシュレッダーダストを削減する必要が出 てきたこと，使用済自動車の不法投棄や不適正な処理の 懸念も生じてきたこと，また，鉱物資源の将来的な枯渇 あ眯念されていることから，2000年に制定された循環 型社会形成推進基本法, 資源有効利用促進法のもと, 2002 年に自動車リサイクル法が制定され 2005 年から本 格施行される。

本報告では，自動車リサイクルの現状と日産自動車の 取り組みについて, おょび, 今後求められる自動車りサ イクルの技術，課題を紹介する。

原稿受付 2004.3.12

*日産自動車(㑣) 車両生産技術本部 リサイクル推進室 連絡先: ₹ 104-8023 東京都中央区銀座 6-17-1 E-mail : t-touhata@mail.nissan.co.jp

\section{2. 自動車リサイクルの現状と課題}

自動車リサイクルの現状について図 1 に示す。

使用済自動車は, 整備事業者や販売会社を経てほぼ $100 \%$ が回収され，中古車として海外に輸出される分を 除き, 年間約 400 万台の使用済み自動車が国内約 3,500 〜 5,000 社の解体事業者により再利用可能な部品が取り 外され, 廃車款 (ガラ) と呼ばれる解体後の車両は, 全 国の約 120 社のシュレッダー会社で破砕され, 鉄スク ラップと, アルミニゥム・銅などの非鉄金属スクラップ 類は製鋼業・精錬業に売却される。

使用済自動車は日米欧とも, 車両重量比で 1 台あたり 約 $80 \%$ が，有用な金属としてリサイクルされ，他の耐 久消費財に対して高水準である。残り $20 \%$ はシュレッ ダーダストとしてほとんどが管理型処分場に埋め立てら れている。車両構成材料とシュレッダーダストの組成を 図 2 に示す。

管理型処分場は建設や管理に手間がかかる上に，国土 の狭い島国である日本においては管理型処分場の残余容 量が減少し, 残余年数は環境省の資料では約 4.3 年 ${ }^{1)}$ と なっている。この結果として, シュレッダーダストの埋 立て処分費用は高騰してきており, 従来のリサイクルシ ステムの改善のために, 新たなリサイクル制度の構築が 求められ, 2002 年に自動車リサイクル法が制定された。 
使用斎み自動車 500万台／年（内 海外輸出 100 万台）
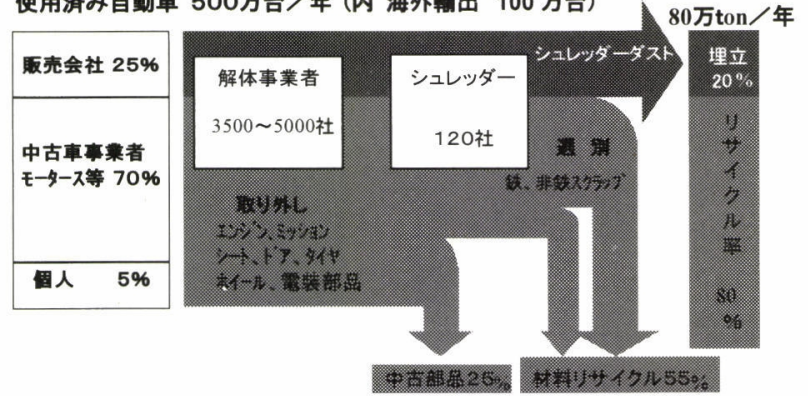

図 1 自動車リサイクルの現状
(3) 使用済み自動車から発生する部品のリ ユース, 材料のリサイクル

使用済み自動車から取り外した部品のリ ユース, 材料のリサイクルは, シュレッダー ダスト量を減らす効果や, 使用済み自動車リ サイクルの経済性を改善する効果の画面で促 進する必要がある。

従来, 新品部品にのみ依存していた補修部 品にリュース品を活用していくことは, ユー ザーの選択肢を広げる意味からも有効である。

また, 自動車には高価で高機能なアルミニ

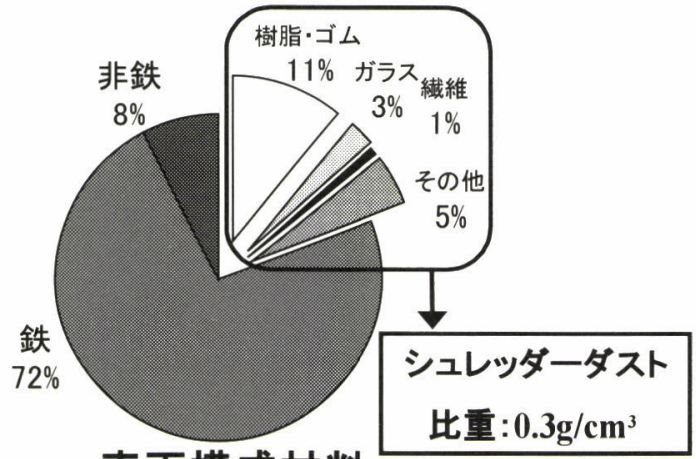

車両構成材料

平均値

図 2 車両構成材料とシュレッダーダストの組成

使用済み自動車のリサイクルでの課題を整理すると以 下の 3 つよなる。

(1) 使用済み自動車のシュレッダーダスト量の削減 最終処分場の逼迫への対策として, シュレッダーダス 卜（成分：プラスチック・絾維・ガラス・ゴムなよ゙）の サーマルリサイクル等の技術の開発と施設整備，および 源流の製品設計段階からシュレッダーダストの削減を 行っていくこと。

(2) 使用済み自動車のリサイクルにおける環境を污さな い適正な処理やリサイクルの促進

鈆・水銀・6 価クロム・カドミウム等の環境負荷物質 の製品設計段階からの削減と使用済み自動車解体時の適 正な処理を実施すること。

オゾン層の破壊や地球温暖化の防止のために, カーエ アコンのフロンの回収と破壊処理を行うこと。

使用段階で衝突時の人身保護のためエアバック類に使 用されているガス発生剂は，以前はアジ化ナトリウムを 使っていたことから，使用済自動車のリサイクルを安全 に実施するために解体段階で適正に処理すること。
ウムも一部使用されており, 現在, アルミニウムは殆ど が回収されリサイクルされているが，一般的に解体工程 では経済的理由により取り外しされずシュレッダー工程 にて回収される。シュレッダー工程にて回収されるアル ミニウムは，様々な規格のアルミ材料が混じった状態で 回収されることから，ダイカスト用等の安価で低グレー ドの材料にリサイクルされているのが実態である。昨今, 車両軽量化のため車体外板等に高機能なアルミニウム展 伸材が使用されていることから, 将来は, 展伸材から展 伸材にリサイクルできる技術開発と回収システムの構築 が必要である。

\section{3. 自動車リサイクル法概要}

\section{1 法律の基本的考え方}

(1)これまで使用済み自動車のリサイクルインフラを 担ってきた現在の関係事業者の役割分担を前提とし つつ, 従来のリサイクルシステムが機能不全となる 主要因であるシュレッダーダスト，および新たな環 境課題であるフロン類，エアバック類への対応を行 う。これにより，市場原理に基づいた使用済自動車 のリサイクル・適正処理の持続的な取り組みの環境 整備を図るとともに，自動車製造業者等の適正な競 争原理が働く仕組みとする。

(2) 使用済自動車から生じる最終埋立て処分量の極小化 を図る。

(3) 不法投育の防止につながる仕組みとする。等

\section{2 法律で規定する関係者の役割分担（関係者の義務）}

(1) 自動車製造業者, 輸入業者

「拡大生産者責任」の考え方に基づき，自らが製造ま たは輸入した自動車が使用済となった場合，その自動車 から発生するフロン類, エアバック類およびシュレッ ダーダストを引き取り, リサイクル（フロン類について は破壊）を適正に行うこと。また，全体システムを検討 
すること。

(2) 自動車所有者

使用済となった自動車を引取業者に引き渡すこと。ま た，処理に必要な費用を支払うこと。

\section{3 リサイクルに必要な費用}

(1) 制度施行後販売される自動車については, 新車販 売時に自動車所有者が費用を支払う。

(2) 制度施行時の既販車については, 最初の車検時等 に自動車所有者が費用を支払う。

(3)リサイクル料金は予め各自動車製造業者等が定め て公表する。

\section{4 リサイクル率}

自動車製造業者は，引き取ったシュレッダーダストに ついて, 表 1 に示す基準に従い, リサイクルを行う。

\section{4. 新型車における環境負荷物質削減目標（自 動車工業会リサイクルイニシアチブ)}

自動車メーカーでは, シュレッダーダストの埋め立て 等による環境への影響を低娍するため，1998年に「リ サイクルイニシアチブ自主行動計画」に沿って環境負荷 物質削減に取り組んできたが，自動車リサイクル法制定 に合わせ，より高い目標を設定した。乗用車の削減対象 物質と削減目標値を表 2 に示す。

\section{5. 日産自動車のリサイクル設計}

\section{1 日産自動車のリサイクル設計への取り組みの経緯}

日産自動車では自動車メーカーでいち早く, 1990 年

表 1 自動車リサイクル法におけるリサイクル率

\begin{tabular}{|l|c|c|c|}
\hline & $\begin{array}{l}\text { 2005年から2009年 } \\
\text { までの各年度 }\end{array}$ & $\begin{array}{l}2010 \text { 年から2014年 } \\
\text { までの各年度 }\end{array}$ & $\begin{array}{l}2015 \text { 年以降 } \\
\text { の各年度 }\end{array}$ \\
\hline $\begin{array}{l}\text { シュレッダーダス } \\
\text { トリサイクル率 }\end{array}$ & $30 \%$ & $50 \%$ & $70 \%$ \\
\hline
\end{tabular}

に「リサイクル推進委員会」を設置し，「再生資源の利 用の促進に関する法律」で規定された製品のリサイクル 性改善の取り組みに着手するとともに，1996年には 「リサイクル推進室」を発足し, 1997 年に解体研究を行 う「リサイクル実証工場」を開設し，使用済み自動車の 適正処理, リサイクル，廃棄物削減などに積極的に取り 組んできた。

日産自動車は, 自動車リサイクル法に先立って展開さ れた経斉産業省の「リサイクルイニシアチブ」で示され た製造事業者としての取り組みを総合的にまとめた『自 動車のリサイクル自主行動計画』を1998 年 2 月に公表 し，以降，着実な取り組みを推進してきている。

これに加えて, 今回公布された自動車リサイクル法へ の対応準備も積極的に取り組みつつある。

\section{2 リイクル設計のための開発プロセス}

リサイクル設計を推進するため, 設計段階で製品のリ サイクル性を事前評価する判断基準を設定し, 開発プロ セスの中で達成状況の評価・管理をしており，このシス テムは環境マネージメントシステム ISO 14001 の認証を 1999 年に取得済みである。

\section{3 日産のリサイクル設計の考え方}

循環型社会の形成に向けて，資源を有効に利用する $3 \mathrm{R}$ の考え方（経済産業省）に基づきリサイクル設計を

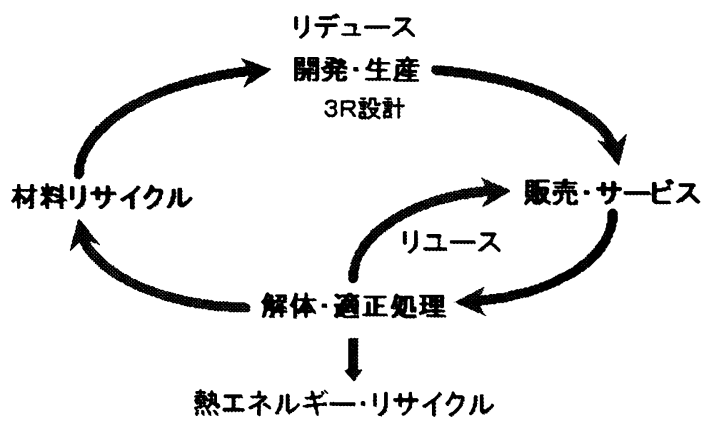

刅 3 日産自動車の $3 \mathrm{R}$ に対する考え方

表 2 「リサイクルイニシアチブ自主行動計画」における乗用車の削減対象物質と削減目標値

\begin{tabular}{|c|c|c|}
\hline 削減物質 & 目標 & 備考 \\
\hline 鉛 & 2006 年 1 月以降の新型車で $1 / 10$ 以下（1996 年比） & $\begin{array}{l}1 \text { ）削減の基準は, } 1996 \text { 年の } 1 \text { 台あたりの鉛使用量代 } \\
\text { 表値である } 1,850 \mathrm{~g} \text { とする。 } \\
2 \text { ） バッテリーは除く }\end{array}$ \\
\hline 水銀 & $\begin{array}{l}\text { 自動車リサイクル法施行時点以降, 以下を除き使用禁止 } \\
\text { 交通安全の観点で使用する以下の部品は除外とする。 } \\
\text { ・ナビゲーション等の液晶ディスプレイ } \\
\text { ・コンビネーションメーター } \\
\text { ・ディスチャージヘッドランプ } \\
\text { ・室内䖢光灯 }\end{array}$ & $\begin{array}{l}\text { 除外部品（極微量に含有）む代替技術の積極的な開発を } \\
\text { 行う。 }\end{array}$ \\
\hline 6 体クロム & 2008 年 1 月以降の新型車で使用禁止 & ボルト等の安全部品で長期使用のための防錆処理に含有 \\
\hline カドミウム & 2007 年 1 月以降の新型車で使用禁止 & 電気, 電子部品 (IC チップ等) で極微量に含有 \\
\hline
\end{tabular}




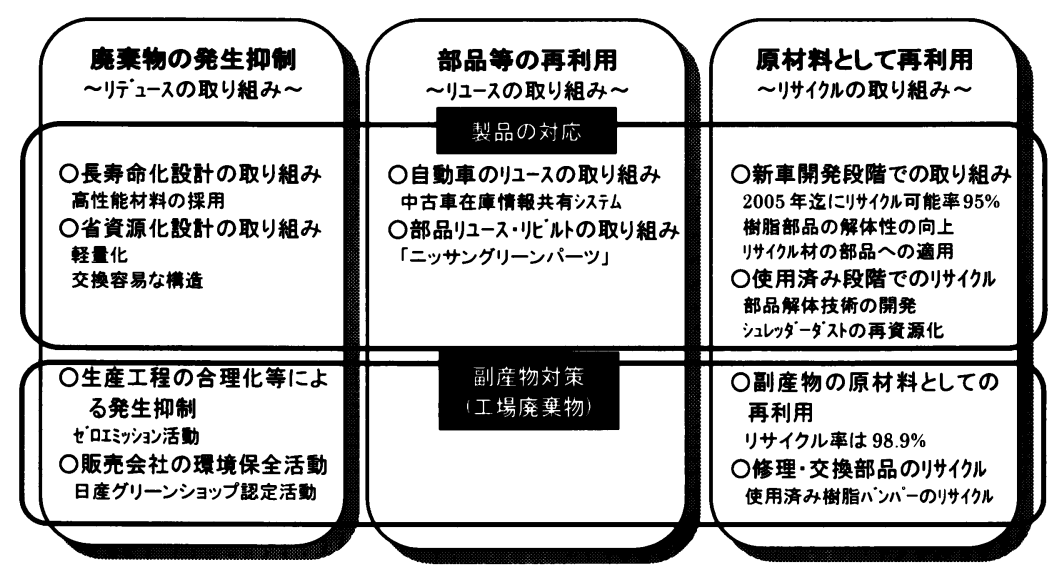

困4 日産自動車の $3 \mathrm{R}$ に対する取り組み

積極的に実施している。（図 3, 図 4)

また, リサイクルしやすい製品設計と呼応した, 使用 済み段階でのリサイクル技術の開発も促進し, リサイク ル率の向上につなげる活動としている。

\section{4 リサイクルしやすい設計のポイント}

\section{4 .1 製品構造}

(1) 車両整備性や部品交換容易性は, リュースやリビ ルトなどリサイクル性と両立し重要なポイントで ある。

(2) 車種間の部品共用化は, リュース部品のマッチン グ率を向上できる。

(3) 部品解体性については, 部品の一体化, 車両への 締結点数削減ととむに，一方向から作業できるな ど分解性がポイントである。

(4) 接着, 溶接, 圧入などは分解しにくく, 可逆的 （もどしやすい）締結構造としていくこと。

(5) エンジンやトランスミッションでは廃油や廃液を より抜き取りやすくする活動に取り組んでいる。

\section{4 .2 使用材料}

プラスチック材料でのリサイクルしやすいポイントは, 単一材料で製品を作ること。熱可塑性樹脂を使用するこ と。材料マーキングを実施すること。

また, 金属材料についてあ, 鉄とアルミニウムを分離 しやすい構造とすること，重金属をできる限り使わない こと。

\section{5 環境負荷物質の削減}

前記, 新型車における環境負荷物質削減目標を達成す るため, 鈶, 水銀, 6 価クロム, カドミウムの代替技術 開発と製品への採用に取り組んでいる。
水銀, カドミゥムについては, 安全上必要な一部の部 品を除き既に代替を完了した。

鉛については, 2003 年式以降の新型車はすべて業界 目標の従来比 $1 / 3$ 人の削減を達成している。

6 価クロムについては，業界目標の前倒し達成に向け 車両適用化検討中である。

\section{6. 製品設計取り組み事例（マーチ：図 5 参照）}

上記で説明した取り組みにより, 発売中のマーチや キューブでは, 部品毎のリサイクル性を格段に改善し, リサイクル可能率 $95 \%$ を達成している。

(1) バンパーでは,

締結点数 32 点 (旧型) $\rightarrow 12$ 点 (新型) とし, 解体 時間を $40 \%$ 短縮した。

(2) インストルメントパネルでは,

上下 2 分割構造とし, 解体時間を $80 \%$ 短縮した。 PP（ポリプロピレン）による単一材料化をはかり, 材料リサイクルを容易にした。

(3) ドアトリムでは,

従来の木, フィルム, 鉄の複合材から新型車では, 単 一材料 PP（ポリプロピレン）に変更し，材料リサイク ル性を向上した。

(4) リヤコンビネーションランプでは,

車体との締結方法において，接着剤を廃止しボルトと することで再利用性を向上した。

\section{7. よ め}

日産自動車におけるリサイクルの取り組みは, 全員 参加の地道な活動により着実に成果を上げている。こ 


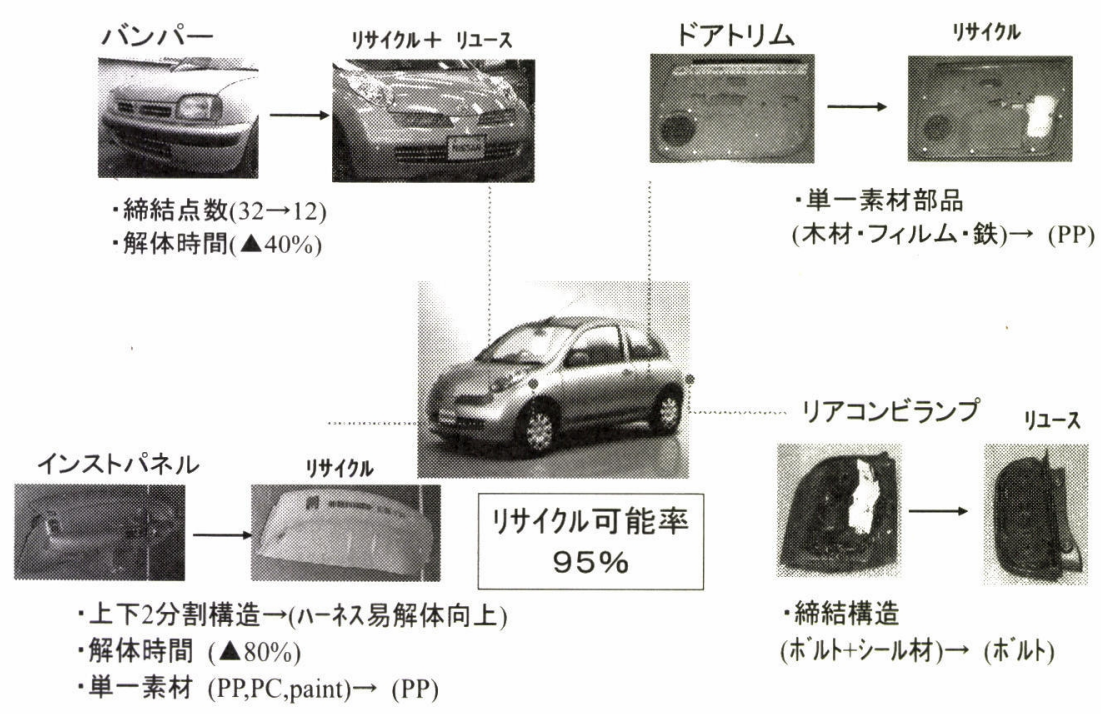

図 5 マーチにおけるリサイクル設計適用事例

れらの活動を通して, 今後の課題も明確になってきてお り，真の持続可能な発展の実現および循環型社会の構築 のためには, Reduce・Reuse・Recycle の個々の取り 組みから, 今後はこれら $3 \mathrm{R}$ の各方策を最適によ゙う組み 合わせていくかを重要な課題之捉えている。Reduce・ Reuse ・ Recycle の優先度を 3 E （Environment・En-
ergy・Economy）の尺度を入れて最適解を追求してい きたい。

\section{参考文献}

1) 環境省：産業廃棄物の排出及び処理状況等（2004）

\title{
Recycling Design Strategies for NISSAN Automobiles
}

\author{
Toru Tohata
}

\begin{abstract}
Vehicle Production Engineering Division Recycling Promotion Department, General Manager (6-17-1 Ginza, chuo-ku, Tokyo, 104-8023 Japan)
\end{abstract}

\begin{abstract}
Although the recycling rate for automobiles is presently over $80 \%$, the best level so far for industrial products, car makers still have work together with the related recycling industries in order to achieve a recovery rate of over $95 \%$ by the year 2015 .

To boost the recycling rate, NISSAN is carrying out a $3 \mathrm{R}$ (Reduce, Reuse, Recycle) design program for new vehicles at the design stage, and developing its recycling technologies for End-ofLife-Vehicles in the recycling stage.

This paper introduces the present status for recycling of End-of-Life-Vehicles, and recycling design technologies at NISSAN, and future tasks to be addressed.
\end{abstract}

Key words : automobile, recycling 